\title{
Pengaruh Waktu Aplikasi dan Dosis Pupuk Kandang Babi Terhadap Pertumbuhan dan Hasil Tanaman Kacang Kedelai (Glycine max, (L.) Merr.)
}

\author{
Yandri Nokas ${ }^{\mathrm{a}}$, Roberto I. C. O. Taolin ${ }^{\mathrm{b}}$, Maria Afnita Lelang ${ }^{\mathrm{c}}$ \\ ${ }^{a}$ Fakultas Pertanian, Universitas Timor, Kefamenanu, TTU - NTT, 85613, Indonesia \\ ${ }^{\mathrm{b}}$ Fakultas Pertanian, Universitas Timor, Kefamenanu, TTU - NTT, 85613, Indonesia, email: ricotaolin@gmail.com \\ c Fakultas Pertanian, Universitas Timor, Kefamenanu, TTU - NTT, 85613, Indonesia, email: afnitalelang@ymail.com
}

\section{Article Info}

\section{Article history:}

Received 27 Agustus 2015

Received in revised form 1 September 2015

Accepted 30 September 2015

Keywords:

Pupuk Kandang Babi

Kedelai

\begin{abstract}
Abstrak
Penelitian ini bertujuan untuk mengetahui pengaruhwaktu aplikasi dan dosis pupuk kandang babi terhadap pertumbuhan dan hasil kacang kedelai sekaligus mendapatkan waktu aplikasi dan dosis pupuk kandang babi yang tepat bagi pertumbuhan dan hasil kacang kedelai. Penelitian mengunakan Rancangan Acak Kelompok (RAK) faktorial 3 x 3 yang diulang tiga kali. Faktor pertama adalah waktu aplikasi pupuk kandang babi yang terdiri dari tiga aras yaitu -7 HST, -14 HST dan -21 HST. Faktor kedua adalah dosis pupuk kandang babi yang terdiri dari tiga aras yaitu $5 \mathrm{t} / \mathrm{ha}, 10 \mathrm{t} / \mathrm{ha}$ dan $15 \mathrm{t} / \mathrm{ha}$. Hasil penelitian menunjukkan tidak terjadi pengaruh interaksi antara waktu aplikasi dan dosis pupuk kandang babi terhadap terhadap semua parameter pertumbuhan dan hasil kedelai. Waktu aplikasi hanya berpengaruh secara nyata terhadap diameter batang 28 HST, sedangkan dosis pupuk berpengaruh secara nyata terhadap tinggi tanaman 14 HST, diameter batang 42 HST, luas daun, berat kering 100 biji dan berat segar maupun berat kering berangkasan. Pemberian pupuk kandang babi pada -14 HST adalah waktu yang tepat dan memberikan hasil kedelai 1,629 t/ha. Dosis $15 \mathrm{t} / \mathrm{ha}$ merupakan dosis yang lebih baik dan memberikan hasil kedelai 1,647 t/ha. Jika pemberian pupuk kandang babi dilakukan pada -14 HST dengan dosis 15 t/ha maka hasil kedelai mencapai 2,090 t/ha. (2016 dipubikasikan oleh Savana Cendana.
\end{abstract}

\section{Pendahuluan}

Kacang kedelai merupakan tanaman pangan berupa semak yang tumbuh tegak, kedelai jenis liar (Glycine ururencis) merupakan kedelai yang dikena sekarang yaitu Glicine max, (L.) Merr. Kedelai berasal dari daerah Mashukuo (Cina Utara) kemudian menyebar di daerah-daerah sekitar bahkan menyebar ke luar negeri. Di Indonesia tanaman ini dibudidayakan mulai abad ke 17 sebagai tanaman pangan, selain itu kedelai juga dikenal sebagai pupuk hijau karena dapat menyuburkan kesuburan tanah (Suprapto, 1997).

Tanaman kedelai salah satu komoditas tanaman pangan yang sanga dibutuhkan oleh penduduk Indonesia dan dipandang penting setelah kacang tanah dan jagung karena merupakan sumber protein nabati, lemak, vitamin dan mineral yang murah. Sebagai bahan makanan kedelai mempunyai kandungan gizi yang tinggi terutama protein (40\%), lemak (20\%), karbohidrat (35\%) dan air $(8 \%)$. Di Indonesia, kedelai banyak diolah untuk berbagai macam bahan pangan, seperti tauge, susu kedelai, tahu, kembang tahu, kecap, oncom, tauco, tempe, es krim, minyak makan dan tepung kedelai. Selain itu juga banyak dimanfaatkan sebagai bahan pakan ternak (Suprapto, 1997).

Seiring dengan bertambahnya jumlah penduduk dan meningkatnya kesejahteraan serta kesadaran masyarakat terhadap kebutuhan akan gizi, maka permintaan akan komoditas kedelai terus meningkat dari tahun ke tahun, akan tetapi kapasitas produksi dalam negeri belakangan ini cenderung menurun Setiap tahunnya pemerintah melakukan impor kedelai yang belakangan ini menurut data BPS (2014) mencapai 1.810.083 ton pada tahun 2013. Salah satu upaya yang dapat dilakukan untuk mengurangi tingginya jumlah impor adalah meningkatkan produksi dalam negeri dengan perbaikan teknologi budidaya seperti pemupukan yang spesifik dengan setiap lokasi. Santoso (1994), menyatakan pemupukan merupakan syarat mutlak dalam membudidayakan suatu tanaman, pemupukan bertujuan untuk menggantikan unsur hara yang hilang karena proses pencucian dan pengangkutan bersama limbah pertanian.

Kesadaran akan pentingnya pertanian berkelanjutan dan kesulitan untuk mendapatkan serta mahalnya harga pupuk anorganik pada kalangan petani mengarahkan untuk pemanfaatan limbah organik yang murah, tersedia dan ramah lingkungan yang bisa digunakan sebagai pupuk organik seperti kotorankotoran hewan ternak seperti babi. Feses merupakan limbah organik yang bersifat biodegradable, yaitu senyawa yang mudah diuraikan oleh mikroorganisme. Suriawiria (2007) menyatakan bahwa feses masih mengandung senyawa yang dibutuhkan oleh tanaman, yaitu nitorgen 5 $7 \%$, pospor 3-6\% dan kalium 1-6\%. Menurut Djadjadiningrat (1991); Harsono (1991), seekor ternak setiap tahunnya menghasilkan feses sebanyak 20,2 $\mathrm{m}^{3}$. Hasil penelitian Ahmed et al. (2013) menunjukkan bahwa pemberian pupuk kandang babi meningkatkan hasil panen kedelai secara signifikan.

Dalam menentukan aplikasi atau penempatan pupuk di tanah harus mempertimbangkan faktor-faktor antara lain tanaman yang akan dipupuk, jenis pupuk yang digunakan, dosis pupuk, cara aplikasi pupuk dan waktu pemupukan. Permasalahan yang melatarbelakangi penelitian ini adalah belum diketahui tentang pengaruh waktu aplikasi dan dosis pupuk kandang babi terhadap pertumbuhan dan hasil tanaman kacang kedelai pada lahan marginal di Kabupaten Timor Tengah Utara.

Penelitian ini bertujuan untuk mengetahui pengaruhwaktu aplikasi dan dosis pupuk kandang babi terhadap pertumbuhan dan hasil kacang kedelai sekaligus mendapatkan waktu aplikasi dan dosis pupuk kandang babi yang tepat bagi pertumbuhan dan hasil kacang kedelai.

\section{Metode}

2.1 Waktu dan Tempat

Penelitian dilaksanakan pada bulan Mei sampai Agustus 2015 di kebun percobaan Fakultas Pertanian, Universitas Timor, Kelurahan Sasi, Kecamatan Kota Kefamenanu, Kabupaten TTU. Topografi berbukit-bukit dengan ketinggian $\pm 400 \mathrm{mdpl}$, curah hujan $900-1.500 \mathrm{~mm}$ per tahun, suhu udara berkisar antara $27^{\circ} \mathrm{C}$ dan $\mathrm{pH}$ tanah netral $(6,5)$ (BPS, 2007).

2.2 Rancangan Percobaan

Penelitian mengunakan Rancangan Acak Kelompok (RAK) faktorial 3 × 3 yang diulang tiga kali. Faktor pertama adalah waktu aplikasi pupuk kandang babi $(\mathrm{W})$ yang terdiri dari tiga aras yaitu $-7 \mathrm{HST}\left(\mathrm{w}_{1}\right),-14 \mathrm{HST}\left(\mathrm{w}_{2}\right)$ dan -21 HST $\left(\mathrm{W}_{3}\right)$. Faktor kedua adalah dosis pupuk kandang babi $(\mathrm{T})$ yang terdiri dari tiga aras yaitu $5 \mathrm{t} / \mathrm{ha}\left(\mathrm{t}_{1}\right), 10 \mathrm{t} / \mathrm{ha}\left(\mathrm{t}_{2}\right)$ dan $15 \mathrm{t} / \mathrm{ha}\left(\mathrm{t}_{3}\right)$. Kombinasi perlakuannya adalahw $\mathrm{w}_{1} \mathrm{t}_{1}, \mathrm{w}_{1} \mathrm{t}_{2}, \mathrm{w}_{1} \mathrm{t}_{3}, \mathrm{w}_{2} \mathrm{t}_{1}, \mathrm{w}_{2} \mathrm{t}_{2}, \mathrm{w}_{2} \mathrm{t}_{3}, \mathrm{w}_{3} \mathrm{t}_{1}, \mathrm{w}_{3} \mathrm{t}_{2}$ dan $\mathrm{w}_{3} \mathrm{t}_{3}$.

2.3 Pelaksanaan Penelitian

a. Persiapan Benih

Benih yang digunakan dalam penelitian ini adalah benih kacang kedelai varietas Lokal yang diperoleh dari petani di Desa Lemon, Kecamatan Miomaffo Barat, Kabupaten TTU. Terlebih dahulu dilakukan seleksi benih dengan cara memilih benih yang berukuran seragam dan bebas dari hama penyakit. Benih yang digunakan dalam penelitian ini sebanyak 2.835 butir dengan benih cadangan sebanyak 5\% sehingga jumlah benih yang disiapkan sebanyak 3.118butir.

b. Pengolahan Tanah

Tanah terlebih dahulu dibersihkan dari gulma serta vegetasi lainnya untuk selanjutnya dilakukan pengolahan. Pengolahan tanah dilakukan dengan menggunakan cangkul, kemudian dilanjutkan dengan penggemburan tanah. Lahan yang digunakan berukuran panjang 17,25 $\mathrm{m}$ dan lebar 7,25 $\mathrm{m}$ dengan luas $125 \mathrm{~m}^{2}$. Lahan dibagi dalam tiga blok dan pada masing-masing blok dibuat sembilan petak percobaan dengan ukuran panjang $1,75 \mathrm{~m}$ dan lebar $1,25 \mathrm{~m}$ sehingga secara keseluruhan terdapat 27 petak. Jarak antara petak $0,5 \mathrm{~m}$ dan jarak antara blok $1 \mathrm{~m}$. Pada setiap blok, petak, tanaman sampel dan tanaman korban diberikan label menggunakan tiang bambu dan seng.

c. Aplikasi Pupuk KandangBabi

Pupuk yang digunakan dalam penelitian ini adalah pupuk kandang yang berasal dari ternak babi yang telah mengalami pengomposan. Pemberian pupuk kandang babi dilakukan dengan cara pembenaman dalam tanah. Waktu aplikasi dan dosis yang digunakan disesuaikan dengan perlakuan. Pada saat -21 HST dibenamkan pupuk pada sembilan petak percobaan dimana tiga petak percobaan diberikan dengan dosis $5 \mathrm{t} / \mathrm{ha}$ atau $1.094 \mathrm{~g}$ per petak, tiga petak percobaan diberikan dengan dosis $10 \mathrm{t} / \mathrm{ha}$ atau $2.188 \mathrm{~g}$ per petak dan tiga petak percobaan diberikan dengan dosis $15 \mathrm{t} / \mathrm{ha}$ atau $3282 \mathrm{~g}$ per petak. Pada saat -14 HST dan -7 HST juga dibenamkan pupuk dengan rincian jumlah petak dan dosis yang sama pada pembenaman sebelumnya. Total kebutuhan pupuk sebanyak $58,97 \mathrm{~kg}$.

d. Penanaman

Penanaman dilakukan pada saat sore hari, dengan cara tugal sedalam \pm 2 $\mathrm{cm}$. Benih ditanam tiga butir per lubang tanam kemudian ditutup dengan tanah, setelah tumbuh, tanaman dijarangkan menyisakan dua tanaman. Jarak tanam yang digunakan adalah $25 \mathrm{~cm} \times 25 \mathrm{~cm}$. Jumlah tanaman dalam setiap petak adalah 35 tanaman dengan jumlah keseluruhan 945 tanaman.

e. Pemeliharaan

Pemeliharaan meliputi penyiraman, penyulaman, penyiangan serta pengendalian hama dan penyakit tanaman. Penyiraman dilakukan menggunakan gembor pada pagi dan sore hari. Penyulaman dilakukan pada saat tanaman berumur 10 HST. Penyulaman dilakukan dengan cara mengganti 
tanaman yang mati atau rusak dengan bibit cadangan yang telah disiapkan Tanaman yang mati atau rusak selama penelitian berjumlah 15 tanaman. Penyiangan terhadap gulma dilakukan dengan mencabutnya. Hama yang menyerang tanaman adalah ulat penggulung daun kedelai Lamprosemaindicata Fabricius (Lepidoptera; Pyralidae). Pengendalian dilakukan dengan cara pengendalian secara fisik yaitu ditangkap.

f. Panen

Panen kedelai dilakukan setelah sebagian besar daun sudah menguning, lalu gugur, buah mulai berubah warna dari hijau menjadi kuning kecoklatan dan retak-retak, atau polong sudah kelihatan tua, batang berwarna kuning agak coklat dan gundul. Panen dilakukan dua kali selama penelitian yakni saat tanaman berumur 88 HST dan 94 HST.

2.4 Parameter Pengamatan

a. Suhu Tanah $\left({ }^{\circ} \mathrm{C}\right)$

Pengukuran suhu tanah dilakukan tiga kali selama penelitian yakni 14 HST, 28HST dan 42 HST, menggunakan thermometer suhu tanah, dengan cara ditancapkan pada kedalaman tanah $5 \mathrm{~cm}$ selama 3 menit pada tiga titik untuk setiap petak. Pengukuran dilakukan pada siang hari pukul 12.00-14.00 WITA.

b. Kadar Lengas Tanah (\%)

Sampel tanah diambil dengan cara menggali sedalam 5 cmpada tiga titik untuk setiap petak. Sampel tanah yang sudah diambil berbentuk gumpalan +2 $\mathrm{cm}$, kemudian disimpan dalam wadah plastik yang ditandai dengan label, kemudian ditimbang untuk mengetahui berat basah, selanjutnya dioven selama 48 jam pada suhu $105{ }^{\circ} \mathrm{C}$, kemudian ditimbang untuk mengetahui berat kering. Pengukuran dilakukan sebanyak tiga kali selama pertumbuhan yakni 14 HST, 28 HST dan 42 HST. Kadar lengas tanah dihitung dengan rumus :

$$
\begin{aligned}
& \mathrm{KL}=\frac{\mathrm{BB}-\mathrm{BK}}{\mathrm{BK}} \times 100 \% \\
\text { Keterangan } & : \\
\mathrm{KL} & : \text { Kadar Lengas Tanah }(\%) \\
\mathrm{BB} & : \text { Berat Basah }(\mathrm{g}) \\
\mathrm{BK} & : \text { Berat Kering }(\mathrm{g})
\end{aligned}
$$

c. Berat Volume Tanah $\left(\mathrm{g} / \mathrm{cm}^{3}\right)$

Sampel tanah kering dari pengukuran kadar lengas tanah kemudian diikat dengan tali raffia sepanjang $10 \mathrm{~cm}$ dan dicelupkan ke dalam cairan lilin dalam wadah alumunium yang dipanaskan dengan lampu spritus. Gumpalan tanah yang telah dilipasi lilin dicelupkan ke dalam gelas ukur berisi air setinggi $40 \mathrm{ml}$ kenaikan volume air dihitung sebagai volume tanah. Berat volume tanah dihitung dengan rumus:

\begin{tabular}{cl} 
& \multicolumn{1}{c}{$\mathrm{BV}=\frac{\mathrm{B}}{\mathrm{V}}$} \\
Keterangan & $:$ \\
$\mathrm{BV}$ & : Berat Volume Tanah $\left(\mathrm{g} / \mathrm{cm}^{3}\right)$ \\
$\mathrm{B}$ & : Berat Tanah Kering $(\mathrm{g})$ \\
$\mathrm{V}$ & : Volume Tanah $\left(\mathrm{cm}^{3}\right)$
\end{tabular}

d. Tinggi Tanaman $(\mathrm{cm})$

Tinggi tanaman diukur dari pangkal batang sampai ujung daun paling tinggi, pengukuran menggunakan pengaris centimeter. Pengukuran dilakukan pada lima tanaman sampel saat berumur 14 HST, 28 HST dan 42 HST.

e. Diameter Batang $(\mathrm{mm})$

Pengukuran diameter batang dilakukan dengan menggunakan jangka sorong dengan cara menjepit pada bagian batang $(1 \mathrm{~cm}$ di atas pangkal batang) dari lima tanaman sampel pada setiap petak. Pengukuran dilakukan pada saat tanaman berumur 14 HST, 28 HST dan 42 HST.

f. Luas Daun $\left(\mathrm{cm}^{2}\right)$

Luas daun diukur pada saat tanaman berumur 49 HST menggunakan metode fotografi dengan cara mengambil semua daun pada lima tanaman sampel pada tiap petak, kemudian daun dipotret menggunakan kamera digital Luas area daun kemudian dihitung menggunakan program ImageJ versi 1,41o. g. Jumlah PolongPer Tanaman

Jumlah polong per tanaman diukur dengan cara menghitung polong yang terbentuk pada lima tanaman sampel kemudian dirata-ratakan.

h. Panjang Polong $(\mathrm{cm})$

Panjang polong diukur dengan menggunakan mistar dari pangkal hingga ujung setiap polong dari lima tanaman sampel kemudian dirata-ratakan.

i. Jumlah Biji Per Polong

Jumlah biji per polongdiukur dengan cara menghitung biji yang terbentuk dalam setiap polong dari lima tanaman sampel kemudian dirata-ratakan.

j. $\quad$ Berat Kering Biji Per Tanaman (g)

Berat kering biji per tanaman diperoleh dengan cara menimbang semua biji pada lima tanaman sampel yang telah dijemur selama satu minggu. Pengukuran dilakukan setiap kali panen kemudian dijumlahkan untuk memperoleh ukuran berat kering biji per tanaman.

k. Berat Kering $100 \mathrm{Biji}(\mathrm{g})$

Diukur dangan cara menimbang 100 biji yang diambil secara acak dari setiap petak yang telah dijemur selama satu minggu. Penimbangan dilakukan tiga kali kemudian dirata-ratakan.

1. Berat Kering Biji Per Petak (t/ha)

Berat kering biji per petak diperoleh dengan cara menimbang semua biji pada setiap petak yang telah dijemur selama satu minggu kemudian dikonversikan ke satuan t/ha. Pengukuran dilakukan setiap kali panen kemudian dijumlahkan untuk memperoleh ukuran berat kering biji per petak total panen

m. Berat Segar Berangkasan(t/ha)

Berat segar berangkasan diukur dengan cara menimbang berangkasan segar semua tanaman dalam setiap petak yang telah dipanen kemudian dikonversikan ke satuan $\mathrm{t} / \mathrm{ha}$. Pengukuran menggunakan timbangan duduk.

n. Berat Kering Berangkasan(t/ha)

Berat kering berangkasan diukur dengan cara menimbang berangkasan semua tanaman dalam setiap petak yang telah dipanen dan dijemur selama satu minggu kemudian dikonversikan ke satuan t/ha. Pengukuran menggunakan timbangan duduk.

o. Indeks Panen (\%)

Indeks panen dihitung dengan cara membandingkan berat bagian tanaman yang bernilai ekonomis dengan berat bagian seluruh tanaman kemudian dikonversikan ke satuan $\%$. Indeks panen dihitung dengan rumus.

$$
\begin{aligned}
& \mathrm{IP}=\frac{\mathrm{A}}{\mathrm{A}+\mathrm{B}} \mathrm{X} 100 \% \\
& \text { IP : Indeks Panen (\%) } \\
& \text { A : Berat Kering Biji Per Petak (t/ha) } \\
& \text { B : Berat Kering Brangkasan ( } \mathrm{t} / \mathrm{ha} \text { ) }
\end{aligned}
$$

\subsection{Analisis Data}

Data hasil pengamatan kemudian dianalisis dengan menggunakan sidik ragam (Anova) Rancangan Acak Kelompok (RAK). Rata-rata perlakuan selanjutnya diuji lanjut dengan menggunakan Duncan Multiple Range Test (DMRT) dengan tingkat signifikan 5\% sesuai petunjuk Gomez dan Gomez (2010). Analisis data menggunakan program SAS 9.1.

\section{Hasil dan Pembahasan}

\subsection{Suhu Tanah}

\begin{tabular}{|c|c|c|c|c|c|}
\hline \multirow{2}{*}{$\begin{array}{c}\text { Waktu } \\
\text { Pengamatan }\end{array}$} & \multirow{2}{*}{ Waktu Aplikasi } & \multicolumn{3}{|c|}{ Dosis Pupuk } & \multirow{2}{*}{ Rerata } \\
\hline & & $5 \mathrm{t} / \mathrm{ha}$ & $10 \mathrm{t} / \mathrm{ha}$ & $15 \mathrm{t} / \mathrm{ha}$ & \\
\hline \multirow{4}{*}{14 HST } & $-7 \mathrm{HST}$ & $31,0 \mathrm{a}$ & $28,4 \mathrm{a}$ & $29,7 \mathrm{a}$ & $29,7 \mathrm{a}$ \\
\hline & -14 HST & 28,9 a & $31,0 \mathrm{a}$ & 29,5 a & $29,8 \mathrm{a}$ \\
\hline & $-21 \mathrm{HST}$ & $29,7 \mathrm{a}$ & $28,6 \mathrm{a}$ & $30,1 \mathrm{a}$ & $29,5 \mathrm{a}$ \\
\hline & Rerata & 29,9 a & $29,3 \mathrm{a}$ & $29,8 \mathrm{a}$ & $(-)$ \\
\hline \multirow{4}{*}{$28 \mathrm{HST}$} & -7 HST & $27,0 \mathrm{a}$ & $27,5 \mathrm{a}$ & $26,9 \mathrm{a}$ & $27,1 \mathrm{a}$ \\
\hline & -14 HST & 26,6 a & $27,5 \mathrm{a}$ & $26,6 \mathrm{a}$ & $26,9 \mathrm{a}$ \\
\hline & $-21 \mathrm{HST}$ & $26,4 \mathrm{a}$ & $26,9 \mathrm{a}$ & $27,1 \mathrm{a}$ & $26,8 \mathrm{a}$ \\
\hline & Rerata & $26,7 \mathrm{a}$ & $27,3 \mathrm{a}$ & $26,9 \mathrm{a}$ & $(-)$ \\
\hline \multirow{4}{*}{$42 \mathrm{HST}$} & -7 HST & $23,6 \mathrm{a}$ & $24,3 \mathrm{a}$ & $24,3 \mathrm{a}$ & $24,0 \mathrm{a}$ \\
\hline & -14 HST & $23,8 \mathrm{a}$ & $24,8 \mathrm{a}$ & $23,8 \mathrm{a}$ & $24,1 \mathrm{a}$ \\
\hline & $-21 \mathrm{HST}$ & $24,3 \mathrm{a}$ & $24,6 \mathrm{a}$ & $22,1 \mathrm{a}$ & $23,7 \mathrm{a}$ \\
\hline & Rerata & $23,9 \mathrm{a}$ & $24,6 \mathrm{a}$ & $23,4 \mathrm{a}$ & $(-)$ \\
\hline
\end{tabular}

Suhu tanah selama penelitian cenderung menurun dari pengamatan awal hingga pengamatan terakhir dengan kisaran suhu antara $22,1-31^{\circ} \mathrm{C}$. Hasil sidik ragam (Anova) menunjukkan tidak terjadi pengaruh interaksi antara waktu aplikasi dan dosis pupuk kandang babiterhadap suhu tanah setiap waktu pengamatan.

( - ): Tidak terjadi interaksi antar factor

Pengaruh utama baik waktu aplikasi maupun dosis pupuk kandang babi juga tidak terjadi secara nyata terhadap suhu tanah setiap waktu pengamatan tetapi data pada Tabel 1. menunjukkan bahwa pemberian pupuk kandang babi pada -14 HST selalu memberikan suhu tanah yang lebih tinggi pada 
pengamatan 14 HST dan 42 HST, sedangkan pada pengamatan 28 HST, suhu tanah pada petak yang diberikan pupuk kandang pada -7 HST lebih tinggi. Pemberian pupuk kandang babi dengan dosis 5 t/ha memberikan suhu tanah yang lebih tinggi pada pengamatan 14 HST, sedangkan pada pengamatan selanjutnya, suhu tanah tertinggi terjadi pada petak yang diberikan pupuk kandang babi dengan dosis $10 \mathrm{t} / \mathrm{ha}$

\subsection{Kadar Lengas Tanah}

Kadar lengas tanah berfluktuasi dan sedikit meningkat dari pengamatan 14 HST hingga pengamatan 28 HST tetapi kemudian menurun hingga pengamatan 42 HST dengan kisaran antara 10,5-30,6\%

\begin{tabular}{|c|c|c|c|c|c|}
\hline \multirow{2}{*}{$\begin{array}{c}\text { Waktu } \\
\text { Pengamatan }\end{array}$} & \multirow{2}{*}{ Waktu Aplikasi } & \multicolumn{3}{|c|}{ Dosis Pupuk } & \multirow{2}{*}{ Rerata } \\
\hline & & $5 \mathrm{t} / \mathrm{ha}$ & $10 \mathrm{t} / \mathrm{ha}$ & $15 \mathrm{t} / \mathrm{ha}$ & \\
\hline \multirow{4}{*}{14 HST } & $-7 \mathrm{HST}$ & $26,1 \mathrm{a}$ & $25,0 \mathrm{a}$ & $24,3 \mathrm{a}$ & $25,1 \mathrm{a}$ \\
\hline & -14 HST & $20,9 \mathrm{a}$ & $24,6 \mathrm{a}$ & $23,6 \mathrm{a}$ & $23,0 \mathrm{a}$ \\
\hline & $-21 \mathrm{HST}$ & 29,8 a & $22,9 \mathrm{a}$ & $24,8 \mathrm{a}$ & $25,9 \mathrm{a}$ \\
\hline & Rerata & $25,6 \mathrm{a}$ & $24,2 \mathrm{a}$ & $24,2 \mathrm{a}$ & $(-)$ \\
\hline \multirow{4}{*}{$28 \mathrm{HST}$} & -7 HST & $27,8 \mathrm{a}$ & $29,0 \mathrm{a}$ & $27,6 \mathrm{a}$ & $28,2 \mathrm{a}$ \\
\hline & -14 HST & $27,5 \mathrm{a}$ & $28,8 \mathrm{a}$ & $30,6 \mathrm{a}$ & $29,0 \mathrm{a}$ \\
\hline & $-21 \mathrm{HST}$ & $29,3 \mathrm{a}$ & $30,5 \mathrm{a}$ & $28,8 \mathrm{a}$ & $29,5 \mathrm{a}$ \\
\hline & Rerata & $28,2 \mathrm{a}$ & $29,5 \mathrm{a}$ & $29,0 \mathrm{a}$ & $(-)$ \\
\hline \multirow{4}{*}{$42 \mathrm{HST}$} & -7 HST & $14,4 \mathrm{a}$ & $15,7 \mathrm{a}$ & $10,5 \mathrm{a}$ & $13,5 \mathrm{a}$ \\
\hline & -14 HST & $22,4 \mathrm{a}$ & $15,4 \mathrm{a}$ & $15,1 \mathrm{a}$ & $17,6 \mathrm{a}$ \\
\hline & $-21 \mathrm{HST}$ & $15,5 \mathrm{a}$ & $16,7 \mathrm{a}$ & $17,5 \mathrm{a}$ & $16,6 \mathrm{a}$ \\
\hline & Rerata & $17,5 \mathrm{a}$ & $15,9 \mathrm{a}$ & $14,3 \mathrm{a}$ & $(-)$ \\
\hline
\end{tabular}

Hasil sidik ragam (Anova) menunjukkan tidak terjadi pengaruh interaksi antara waktu aplikasi dan dosis pupuk kandang babi terhadap kadar lengas tanah setiap waktu pengamatan.

Pengaruh utama baik waktu aplikasi maupun dosis pupuk kandang babi juga tidak terjadi secara nyata terhadap kadar lengas tanah setiap waktu pengamatan tetapi data pada Tabel 2. menunjukkan bahwa pemberian pupuk kandang babi pada -21 HST memberikan kadar lengas tanah yang selalu lebih tinggi pada pengamatan 14 HST dan 28 HST, tetapi pada pengamatan 42 HST, kadar lengas tanah pada petak yang diberikan pupuk kandang pada -14 HST lebih tinggi. Pemberian pupuk kandang babi dengan dosis $5 \mathrm{t} / \mathrm{ha}$ memberikan kadar lengas tanah yang lebih tinggi pada pengamatan 14 HST dan 42 HST, sedangkan pada pengamatan 14 HST, kadar lengas tanah pada petak yang diberikan pupuk kandang babi dengan dosis 10 t/ha lebih tinggi.

3.3 Berat Volume Tanah

Berat volume tanah selama penelitian berkisar antara 1,4-1,6 g/ $\mathrm{cm}^{3}$. Hasil sidik ragam (Anova) menunjukkan tidak terjadi pengaruh interaksi antara waktu aplikasi dan dosis pupuk kandang babi terhadap berat volume tanah setiap waktu pengamatan.

Pengaruh utama baik waktu aplikasi maupun dosis pupuk kandang babi juga tidak terjadi secara nyata terhadap berat volume tanah setiap waktu pengamatan tetapi data pada Tabel 3. menunjukkan bahwa pada pengamatan 14 HST, berat volume tanah pada petak yang diberikan pupuk kandang pada -7 HST lebih tinggi, pada pengamatan $28 \mathrm{HST}$, berat volume tanah pada petak yang diberikan pupuk kandang pada -14 HST lebih tinggi dan pada pengamatan 42 HST, berat volume tanah pada petak yang diberikan pupuk kandang pada -7 HST dan -21 HST lebih tinggi. Pemberian pupuk kandang babi dengan dosis 10 t/ha memberikan berat volume tanah yang lebih tinggi pada pengamatan 14 HST, selanjutnya pada pengamatan 28 HST, berat volume tanah pada petak yang diberikan pupuk kandang babi dengan dosis 5 t/ha lebih tinggi, pada pengamatan $42 \mathrm{HST}$, berat volume tanah pada petak yang diberikan pupuk kandang babi dengan dosis 5 t/ha dan 15 t/ha lebih tinggi.

\begin{tabular}{|c|c|c|c|c|c|}
\hline \multirow{2}{*}{$\begin{array}{c}\text { Waktu } \\
\text { Pengamatan }\end{array}$} & \multirow{2}{*}{ Waktu Aplikasi } & \multicolumn{3}{|c|}{ Dosis Pupuk } & \multirow{2}{*}{ Rerata } \\
\hline & & $5 \mathrm{t} / \mathrm{ha}$ & $10 \mathrm{t} / \mathrm{ha}$ & $15 \mathrm{t} / \mathrm{ha}$ & \\
\hline \multirow{4}{*}{14 HST } & $-7 \mathrm{HST}$ & $1,4 \mathrm{a}$ & $1,5 \mathrm{a}$ & $1,4 \mathrm{a}$ & $1,4 \mathrm{a}$ \\
\hline & -14 HST & $1,5 \mathrm{a}$ & $1,5 \mathrm{a}$ & $1,4 \mathrm{a}$ & $1,4 \mathrm{a}$ \\
\hline & $-21 \mathrm{HST}$ & $1,4 \mathrm{a}$ & $1,5 \mathrm{a}$ & $1,5 \mathrm{a}$ & $1,5 \mathrm{a}$ \\
\hline & Rerata & $1,4 \mathrm{a}$ & $1,5 \mathrm{a}$ & $1,4 \mathrm{a}$ & $(-)$ \\
\hline \multirow{4}{*}{$28 \mathrm{HST}$} & -7 HST & $1,6 \mathrm{a}$ & $1,5 \mathrm{a}$ & $1,5 \mathrm{a}$ & $1,5 \mathrm{a}$ \\
\hline & -14 HST & $1,5 \mathrm{a}$ & $1,5 \mathrm{a}$ & $1,6 \mathrm{a}$ & $1,6 \mathrm{a}$ \\
\hline & $-21 \mathrm{HST}$ & $1,5 \mathrm{a}$ & $1,5 \mathrm{a}$ & $1,5 \mathrm{a}$ & $1,5 \mathrm{a}$ \\
\hline & Rerata & $1,6 \mathrm{a}$ & $1,5 \mathrm{a}$ & $1,5 \mathrm{a}$ & $(-)$ \\
\hline \multirow{4}{*}{$42 \mathrm{HST}$} & -7 HST & $1,6 \mathrm{a}$ & $1,6 \mathrm{a}$ & $1,6 \mathrm{a}$ & $1,6 \mathrm{a}$ \\
\hline & -14 HST & $1,6 \mathrm{a}$ & $1,4 \mathrm{a}$ & $1,6 \mathrm{a}$ & $1,5 \mathrm{a}$ \\
\hline & $-21 \mathrm{HST}$ & $1,5 \mathrm{a}$ & $1,6 \mathrm{a}$ & $1,6 \mathrm{a}$ & $1,6 \mathrm{a}$ \\
\hline & Rerata & $1,6 \mathrm{a}$ & $1,5 \mathrm{a}$ & $1,6 \mathrm{a}$ & $(-)$ \\
\hline
\end{tabular}

\subsection{Tinggi Tanaman}

Tanaman terus bertambah tinggi selama penelitian. Hasil sidik ragam (Anova) menunjukkan tidak terjadi pengaruh interaksi antara waktu aplikasi dan dosis pupuk kandang babi terhadap tinggi tanaman setiap waktu pengamatan, tetapi hasil uji lanjut menunjukkan bahwa saat pengamatan 14 HST, kedelai yang diberikan pupuk kandang babi pada -7 HST dengan dosis 10 t/ha paling tinggi dan berbeda nyata dengan tinggi tanaman kedelai yang diberikan pupuk kandang babi pada -14 HST dengan dosis 5 t/ha tetapi tidak berbeda nyata dengan tinggi tanaman dari kombinasi perlakuan lainnya. Sedangkan pada pengamatan selanjutnya, kedelai yang diberikan pupuk kandang babi pada -14 HST dengan dosis 15 t/ha selalu paling tinggi dan berbeda nyata dengan tinggi tanaman kedelai yang diberikan pupuk kandang babi pada waktu yang sama dengan dosis 10 t/ha tetapi tidak berbeda nyata dengan tinggi tanaman dari kombinasi perlakuan lainnya.

Waktu aplikasi pupuk kandang babi tidak berpengaruh secara nyata terhadap tinggi tanaman setiap waktu pengamatan, tetapi dari data pada Tabel 4 . diketahui bahwa saat pengamatan 14 HST, kedelai yang diberikan pupuk kandang babi pada -21 HST lebih tinggi tetapi pada pengamatan selanjutnya yakni 28 HST dan 42 HST, kedelai yang diberikan pupuk kandang babi pada -7 HST lebih tinggi dan sebaliknya kedelai yang diberikan pupuk kandang babi pada -21 HST paling pendek.

Dosis pupuk kandang babi berpengaruh secara nyata terhadap tinggi tanaman pada pengamatan 14 HST dimana kedelai yang diberikan pupuk kandang babi dengan dosis 10 t/ha paling tinggi dan berbeda nyata dengan tinggi tanaman kedelai yang diberikan pupuk kandang babi dengan dosis 5 t/ha maupun $15 \mathrm{t} / \mathrm{ha}$. Sebaliknya pada pengamatan selanjutnya yakni 28 HST dan 42 HST dosis pupuk kandang babi tidak berpengaruh nyata terhadap tinggi tanaman dan data Tabel 4. menunjukkan bahwa kedelai yang diberikan pupuk kandang babi dengan dosis $15 \mathrm{t} / \mathrm{ha}$ selalu lebih tinggi sedangkan kedelai yang diberikan pupuk kandang babi dengan dosis 10 t/ha selalu lebih pendek. 
Tabel 4. Tinggi Tanaman $(\mathrm{cm})$

\begin{tabular}{|c|c|c|c|c|c|}
\hline \multirow{2}{*}{$\begin{array}{c}\text { Waktu } \\
\text { Pengamatan }\end{array}$} & \multirow{2}{*}{ Waktu Aplikasi } & \multicolumn{3}{|c|}{ Dosis Pupuk } & \multirow{2}{*}{ Rerata } \\
\hline & & $5 \mathrm{t} / \mathrm{ha}$ & $10 \mathrm{t} / \mathrm{ha}$ & $15 \mathrm{t} / \mathrm{ha}$ & \\
\hline \multirow{4}{*}{$14 \mathrm{HST}$} & $-7 \mathrm{HST}$ & $15,0 \mathrm{ab}$ & $16,1 \mathrm{a}$ & $14,8 \mathrm{ab}$ & $15,3 \mathrm{a}$ \\
\hline & -14 HST & $14,3 \mathrm{~b}$ & $15,6 \mathrm{a}$ & $15,5 \mathrm{ab}$ & $15,1 \mathrm{a}$ \\
\hline & $-21 \mathrm{HST}$ & $15,8 \mathrm{a}$ & $15,8 \mathrm{a}$ & $15,2 \mathrm{ab}$ & $15,6 \mathrm{a}$ \\
\hline & Rerata & $15,0 \mathrm{~b}$ & $15,8 \mathrm{a}$ & $15,1 \mathrm{~b}$ & $(-)$ \\
\hline \multirow{4}{*}{$28 \mathrm{HST}$} & -7 HST & $28,0 \mathrm{a}$ & $25,5 \mathrm{ab}$ & $26,1 \mathrm{ab}$ & $26,6 \mathrm{a}$ \\
\hline & -14 HST & $23,6 \mathrm{ab}$ & $22,6 \mathrm{~b}$ & $28,0 \mathrm{a}$ & $24,7 \mathrm{a}$ \\
\hline & $-21 \mathrm{HST}$ & $23,9 \mathrm{ab}$ & $24,8 \mathrm{ab}$ & $24,0 \mathrm{ab}$ & $24,2 \mathrm{a}$ \\
\hline & Rerata & $25,2 \mathrm{a}$ & $24,3 \mathrm{a}$ & $26,0 \mathrm{a}$ & $(-)$ \\
\hline \multirow{4}{*}{$42 \mathrm{HST}$} & -7 HST & $45,4 \mathrm{a}$ & $38,6 \mathrm{ab}$ & $40,8 \mathrm{ab}$ & $41,6 \mathrm{a}$ \\
\hline & -14 HST & $37,2 \mathrm{ab}$ & $32,8 \mathrm{~b}$ & $46,0 \mathrm{a}$ & $38,7 \mathrm{a}$ \\
\hline & $-21 \mathrm{HST}$ & $35,4 \mathrm{ab}$ & $36,3 \mathrm{ab}$ & $37,2 \mathrm{ab}$ & $36,3 \mathrm{a}$ \\
\hline & Rerata & $39,3 \mathrm{a}$ & $35,9 \mathrm{a}$ & $41,3 \mathrm{a}$ & $(-)$ \\
\hline
\end{tabular}

$(-)$ : Tidak terjadi interaksi antar faktor

3.5 Diameter Batang

Batang tanaman terus bertambah besar selama penelitian. Hasil sidik ragam (Anova) menunjukkan tidak terjadi pengaruh interaksi antara waktu aplikasi dan dosis pupuk kandang babi terhadap diameter batang setiap waktu pengamatan, tetapi hasil uji lanjut menunjukkan bahwa saat pengamatan 28
HST dan 42 HST, kedelai yang diberikan pupuk kandang babi pada -7 HST dengan dosis $15 \mathrm{t} /$ ha selalu memiliki diameter batang yang paling besar dan berbeda nyata dengan diameter batang kedelai dari beberapa kombinasi perlakuan lainnya.

Tabel 5. Diameter Batang (mm)

\begin{tabular}{|c|c|c|c|c|c|}
\hline \multirow{2}{*}{$\begin{array}{c}\text { Waktu } \\
\text { Pengamatan }\end{array}$} & \multirow{2}{*}{ Waktu Aplikasi } & \multicolumn{3}{|c|}{ Dosis Pupuk } & \multirow{2}{*}{ Rerata } \\
\hline & & $5 \mathrm{t} / \mathrm{ha}$ & $10 \mathrm{t} / \mathrm{ha}$ & $15 \mathrm{t} / \mathrm{ha}$ & \\
\hline \multirow{4}{*}{$14 \mathrm{HST}$} & $-7 \mathrm{HST}$ & $0,46 \mathrm{a}$ & $0,46 \mathrm{a}$ & $0,47 \mathrm{a}$ & $0,46 \mathrm{a}$ \\
\hline & -14 HST & $0,47 \mathrm{a}$ & $0,45 \mathrm{a}$ & $0,46 \mathrm{a}$ & $0,46 \mathrm{a}$ \\
\hline & $-21 \mathrm{HST}$ & $0,47 \mathrm{a}$ & $0,44 \mathrm{a}$ & $0,46 \mathrm{a}$ & $0,45 \mathrm{a}$ \\
\hline & Rerata & $0,47 \mathrm{a}$ & $0,45 \mathrm{a}$ & $0,46 \mathrm{a}$ & $(-)$ \\
\hline \multirow{4}{*}{$28 \mathrm{HST}$} & -7 HST & $0,66 a b c$ & $0,68 \mathrm{ab}$ & $0,70 \mathrm{a}$ & $0,68 \mathrm{a}$ \\
\hline & -14 HST & $0,66 \mathrm{abc}$ & $0,63 \mathrm{bc}$ & $0,65 \mathrm{bc}$ & $0,65 \mathrm{~b}$ \\
\hline & $-21 \mathrm{HST}$ & $0,66 \mathrm{abc}$ & $0,62 \mathrm{c}$ & $0,65 \mathrm{bc}$ & $0,64 \mathrm{~b}$ \\
\hline & Rerata & $0,66 \mathrm{a}$ & $0,64 \mathrm{a}$ & $0,67 \mathrm{a}$ & $(-)$ \\
\hline \multirow{4}{*}{$42 \mathrm{HST}$} & -7 HST & $0,82 \mathrm{~b}$ & $0,86 a b$ & $0,91 \mathrm{a}$ & $0,86 \mathrm{a}$ \\
\hline & -14 HST & $0,82 \mathrm{~b}$ & $0,84 \mathrm{~b}$ & $0,86 \mathrm{ab}$ & $0,84 \mathrm{a}$ \\
\hline & $-21 \mathrm{HST}$ & $0,85 \mathrm{ab}$ & $0,81 \mathrm{~b}$ & $0,84 \mathrm{~b}$ & $0,84 \mathrm{a}$ \\
\hline & Rerata & $0,83 \mathrm{~b}$ & $0,84 \mathrm{ab}$ & $0,87 \mathrm{a}$ & $(-)$ \\
\hline
\end{tabular}

Kedelai yang diberikan pupuk kandang babi pada -7 HST selalu memiliki diameter batang yang lebih besar pada setiap waktu pengamatan, tetapi saat 14 HST dan 42 HST pengaruh waktu aplikasi pupuk kandang babi tidak terjadi secara nyata dan waktu aplikasi hanya berpengaruh secara nyata terhadap diameter batang saat 28 HST.

Dosis pupuk kandang babi tidak berpengaruh secara nyata terhadap diameter batang pada pengamatan 14 HST dan 28 HST tetapi data Tabel 5. menunjukkan bahwa saat 14 HST, kedelai yang diberikan pupuk kandang babi dengan dosis 5 t/ha memiliki diameter batang yang lebih besar, tetapi saat 28 HST kedelai yang diberikan pupuk kandang babi dengan dosis $15 \mathrm{t} / \mathrm{ha}$ memiliki diameter batang yang lebih besar. Pada pengamatan 42 HST dosis pupuk kandang babi berpengaruh secara nyata terhadap diameter batang dimana kedelai yang diberikan pupuk kandang babi dengan dosis 15 t/ha memiliki diameter batang yang paling besar dan berbeda nyata dengan diameter batang kedelai yang diberikan pupuk kandang babi dengan dosis 5 t/ha.

3.6 Luas Daun
Hasil sidik ragam (Anova) menunjukkan tidak terjadi pengaruh interaksi antara waktu aplikasi dan dosis pupuk kandang babi terhadap luas daun, tetapi hasil uji lanjut menunjukkan bahwa kedelai yang diberikan pupuk kandang babi pada -7 HST dengan dosis 10 t/ha memiliki permukaan daun yang paling luas dan berbeda nyata dengan luas daun kedelai yang diberikan pupuk kandang babi pada -7 HST dan -14 HST dengan dosis 10 t/ha tetapi tidak berbeda nyata dengan luas daun kedelai dari kombinasi perlakuan yang lainnya.

Waktu aplikasi tidak berpengaruh secara nyata terhadap luas daun tetapi data pada Tabel 6. menunjukkan bahwa kedelai yang diberikan pupuk kandang babi pada -7 HST memiliki permukaan daun yang cenderung lebih luas sedangkan permukaan daun kedelai yang diberikan pupuk kandang babi pada 21 HST paling sempit. Dosis pupuk kandang babi berpengaruh secara nyata terhadap luas daun dimana kedelai yang diberikan pupuk kandang babi dengan dosis 5 t/ha memiliki permukaan daun yang paling luas dan berbeda nyata dengan luas daun kedelai yang diberikan pupuk kandang babi dengan dosis 10 t/ha.

\begin{tabular}{|c|c|c|c|c|}
\hline \multirow{2}{*}{ Waktu Aplikasi } & \multicolumn{3}{|c|}{ Dosis Pupuk } & \multirow{2}{*}{ Rerata } \\
\hline & $5 \mathrm{t} / \mathrm{ha}$ & $10 \mathrm{t} / \mathrm{ha}$ & $15 \mathrm{t} / \mathrm{ha}$ & \\
\hline-7 HST & $1225,4 \mathrm{a}$ & $427,2 \mathrm{~b}$ & $798,0 \mathrm{ab}$ & $816,9 \mathrm{a}$ \\
\hline-14 HST & $938,6 \mathrm{ab}$ & $543,5 \mathrm{~b}$ & $924,7 \mathrm{ab}$ & $802,2 \mathrm{a}$ \\
\hline$-21 \mathrm{HST}$ & $704,9 \mathrm{ab}$ & $700,5 \mathrm{ab}$ & $693,6 \mathrm{ab}$ & $699,7 \mathrm{a}$ \\
\hline Rerata & $956,3 \mathrm{a}$ & $557,1 \mathrm{~b}$ & $805,4 \mathrm{ab}$ & $(-)$ \\
\hline
\end{tabular}

\subsection{Jumlah Polong Per Tanaman}

Hasil sidik ragam (Anova) menunjukkan tidak terjadi pengaruh interaksi antara waktu aplikasi dan dosis pupuk kandang babi terhadap jumlah polong per tanaman.

Pengaruh utama baik waktu aplikasi maupun dosis pupuk kandang babi tidak terjadi secara nyata terhadap jumlah polong per tanaman tetapi data pada Tabel 7. menunjukkan bahwa kedelai yang diberikan pupuk kandang babi pada
-7 HST memiliki polong setiap tanaman yang lebih banyak sedangkan kedelai yang diberikan pupuk kandang babi pada -21 HST memiliki polong setiap tanaman yang paling sedikit. Kedelai yang diberikan pupuk kandang babi dengan dosis 15 t/ha memiliki polong setiap tanaman yang lebih banyak sedangkan kedelai yang diberikan pupuk kandang babi dengan dosis 10 t/ha memiliki polong setiap tanaman yang paling sedikit. 
Tabel 7. Jumlah Polong Per Tanaman

\begin{tabular}{ccccc}
\hline \multirow{2}{*}{ Waktu Aplikasi } & \multicolumn{3}{c}{ Dosis Pupuk } & \multirow{2}{*}{ Rerata } \\
\cline { 2 - 4 } & $5 \mathrm{t} / \mathrm{ha}$ & $10 \mathrm{t} / \mathrm{ha}$ & $40,3 \mathrm{a}$ \\
-7 HST & $43,1 \mathrm{a}$ & $37,7 \mathrm{a}$ & $40,2 \mathrm{a}$ & $35,5 \mathrm{a}$ \\
-14 HST & $32,8 \mathrm{a}$ & $27,6 \mathrm{a}$ & $46,0 \mathrm{a}$ & $31,1 \mathrm{a}$ \\
\hline -21 HST & $27,7 \mathrm{a}$ & $29,7 \mathrm{a}$ & $36,0 \mathrm{a}$ & $(-)$ \\
\hline Rerata & $34,5 \mathrm{a}$ & $31,6 \mathrm{a}$ & $40,7 \mathrm{a}$ & \\
\hline Keterangan : & Angka pada baris dan kolom yang diikuti dengan huruf yang samatidak berbeda nyata menurut uji DMRT @ 5\%.
\end{tabular}

( - ): Tidak terjadi interaksi antar faktor

\subsection{Panjang Polong}

Hasil sidik ragam (Anova) menunjukkan tidak terjadi pengaruh interaksi antara waktu aplikasi dan dosis pupuk kandang babi terhadap panjang polong.

Pengaruh utama baik waktu aplikasi maupun dosis pupuk kandang babi tidak terjadi secara nyata terhadap panjang polong tetapi data pada Tabel 8 . menunjukkan bahwa kedelai yang diberikan pupuk kandang babi pada -14 HST dan 21 HST memiliki polong yang lebih panjang dibandingkan kedelai yang diberikan pupuk kandang babi pada -7 HST. Kedelai yang diberikan pupuk kandang babi dengan dosis $15 \mathrm{t} / \mathrm{ha}$ memiliki polong yang lebih panjang dibandingkan kedelai yang diberikan pupuk kandang babi dengan dosis 5 t/ha dan 10 t/ha.

Tabel 8. Panjang Polong (cm)

\begin{tabular}{|c|c|c|c|c|}
\hline \multirow[b]{2}{*}{ Waktu Aplikasi } & \multicolumn{3}{|c|}{ Dosis Pupuk } & \multirow[b]{2}{*}{ Rerata } \\
\hline & $5 \mathrm{t} / \mathrm{ha}$ & $10 \mathrm{t} / \mathrm{ha}$ & $15 \mathrm{t} / \mathrm{ha}$ & \\
\hline-7 HST & $3,6 \mathrm{a}$ & $3,4 \mathrm{a}$ & $3,5 \mathrm{a}$ & $3,5 \mathrm{a}$ \\
\hline-14 HST & $3,5 \mathrm{a}$ & $3,5 \mathrm{a}$ & $3,7 \mathrm{a}$ & $3,6 \mathrm{a}$ \\
\hline$-21 \mathrm{HST}$ & $3,5 \mathrm{a}$ & $3,7 \mathrm{a}$ & $3,7 \mathrm{a}$ & $3,6 \mathrm{a}$ \\
\hline Rerata & $3,5 \mathrm{a}$ & $3,5 \mathrm{a}$ & $3,6 \mathrm{a}$ & $(-)$ \\
\hline
\end{tabular}

\subsection{Jumlah Biji Per Polong}

Hasil sidik ragam (Anova) menunjukkan tidak terjadi pengaruh interaksi antara waktu aplikasi dan dosis pupuk kandang babi terhadap jumlah biji per polong, tetapi hasil uji lanjut menunjukkan bahwa kedelai yang diberikan pupuk kandang babi pada -21 HST dengan dosis 10 t/ha memiliki biji setiap polong yang paling banyak dan berbeda nyata dengan jumlah biji per polong dari kombinasi perlakuan yang lain tetapi tidak berbeda nyata dengan jumlah biji per polong kedelai yang diberikan pupuk kandang babi pada -14 HST dengan dosis $15 \mathrm{t} / \mathrm{ha}$.
Pengaruh utama baik waktu aplikasi maupun dosis pupuk kandang babi tidak terjadi secara nyata terhadap jumlah biji per polong tetapi data pada Tabel 9. menunjukkan bahwa kedelai yang diberikan pupuk kandang babi pada -21 HST memiliki biji setiap polong yang lebih banyak dibandingkan jumlah biji per polong kedelai yang diberikan pupuk kandang babi pada -7 HST dan 14 HST. Kedelai yang diberikan pupuk kandang babi dengan dosis $10 \mathrm{t} / \mathrm{ha}$ memiliki biji setiap polong yang lebih banyak sedangkan kedelai yang diberikan pupuk kandang babi dengan dosis 5 t/ha memiliki biji setiap polong yang paling sedikit.

Tabel 9. Jumlah Biji Per Polong

\begin{tabular}{|c|c|c|c|c|}
\hline \multirow{2}{*}{ Waktu Aplikasi } & \multicolumn{3}{|c|}{ Dosis Pupuk } & \multirow{2}{*}{ Rerata } \\
\hline & $5 \mathrm{t} / \mathrm{ha}$ & $10 \mathrm{t} / \mathrm{ha}$ & $15 \mathrm{t} / \mathrm{ha}$ & \\
\hline-7 HST & $2,3 \mathrm{~b}$ & $2,1 \mathrm{~b}$ & $2,2 \mathrm{~b}$ & $2,2 \mathrm{a}$ \\
\hline-14 HST & $2,2 \mathrm{~b}$ & $2,0 \mathrm{~b}$ & $2,5 \mathrm{ab}$ & $2,2 \mathrm{a}$ \\
\hline$-21 \mathrm{HST}$ & $1,9 \mathrm{~b}$ & $3,1 \mathrm{a}$ & $1,9 \mathrm{~b}$ & $2,3 \mathrm{a}$ \\
\hline Rerata & $2,1 \mathrm{a}$ & $2,4 \mathrm{a}$ & $2,2 \mathrm{a}$ & $(-)$ \\
\hline
\end{tabular}

\subsection{Berat Kering Biji Per Tanaman}

Hasil sidik ragam (Anova) menunjukkan tidak terjadi pengaruh interaksi antara waktu aplikasi dan dosis pupuk kandang babi terhadap berat kering biji per tanaman.

Pengaruh utama baik waktu aplikasi maupun dosis pupuk kandang babi tidak terjadi secara nyata terhadap berat kering biji per tanaman tetapi data Tabel 10. menunjukkan bahwa kedelai yang diberikan pupuk kandang babi pada -7 HST menghasilkan biji kering setiap tanaman yang lebih berat sedangkan kedelai yang diberikan pupuk kandang babi pada -21 HST menghasilkan biji kering setiap tanaman yang paling ringan. Kedelai yang diberikan pupuk kandang babi dengan dosis 15 t/ha menghasilkan biji kering setiap tanaman yang yang lebih berat sedangkan kedelai yang diberikan pupuk kandang babi dengan dosis 10 t/ha menghasilkan biji kering setiap tanaman yang paling ringan.

Tabel 10. Berat Kering Biji Per Tanaman (g)

\begin{tabular}{ccccc}
\hline \multirow{2}{*}{ Waktu Aplikasi } & \multicolumn{3}{c}{ Dosis Pupuk } & \multirow{2}{*}{ Rerata } \\
\cline { 2 - 4 } & $5 \mathrm{t} / \mathrm{ha}$ & $10 \mathrm{t} / \mathrm{ha}$ & $15 \mathrm{t} / \mathrm{ha}$ & $10,1 \mathrm{a}$ \\
-7 HST & $10,4 \mathrm{a}$ & $9,9 \mathrm{a}$ & $10,1 \mathrm{a}$ & $9,5 \mathrm{a}$ \\
$-14 \mathrm{HST}$ & $9,2 \mathrm{a}$ & $7,3 \mathrm{a}$ & $12,1 \mathrm{a}$ & $7,5 \mathrm{a}$ \\
\hline -21 HST & $6,1 \mathrm{a}$ & $7,5 \mathrm{a}$ & $9,0 \mathrm{a}$ & $(-)$ \\
\hline Rerata & $8,6 \mathrm{a}$ & $8,2 \mathrm{a}$ & $10,4 \mathrm{a}$ & \\
\hline Keterangan : & Angka pada baris dan kolom yang dikuti dengan huruf yang samatidak berbeda nyata menurut uji DMRT @ 5\%.
\end{tabular}

( - ) : Tidak terjadi interaksi antar faktor

\subsection{Berat Kering 100 Biji}

Hasil sidik ragam (Anova) menunjukkan tidak terjadi pengaruh interaksi antara waktu aplikasi dan dosis pupuk kandang babi terhadap berat kering 100 biji, tetapi hasil uji lanjut menunjukkan bahwa kedelai yang diberikan pupuk kandang babi pada -7 HST dengan dosis 10 t/ha menghasilkan setiap 100 biji kering yang paling berat yang berbeda nyata dengan berat kering $100 \mathrm{biji}$ kedelai yang diberikan pupuk kandang babi pada waktu yang sama dengan dosis 15 t/ha serta kedelai yang diberikan pupuk kandang babi pada -14 HST dengan dosis $10 \mathrm{t} / \mathrm{ha}$ dan $15 \mathrm{t} / \mathrm{ha}$ tetapi tidak berbeda nyata dengan kombinasi perlakuan yang lainnya.

Tabel 11. Berat Kering 100 Biji (g)

\begin{tabular}{ccccc}
\hline \multirow{2}{*}{ Waktu Aplikasi } & \multicolumn{3}{c}{ Dosis Pupuk } & \multirow{2}{*}{ Rerata } \\
\cline { 2 - 4 } & $5 \mathrm{t} / \mathrm{ha}$ & $10 \mathrm{t} / \mathrm{ha}$ & $15 \mathrm{t} / \mathrm{ha}$ & $11,8 \mathrm{a}$ \\
- -7 HST & $11,7 \mathrm{ab}$ & $12,8 \mathrm{a}$ & $10,9 \mathrm{~b}$ & $11,3 \mathrm{a}$ \\
$-21 \mathrm{HST}$ & $11,7 \mathrm{ab}$ & $11,3 \mathrm{~b}$ & $11,0 \mathrm{~b}$ & $11,9 \mathrm{a}$ \\
\hline Rerata & $11,7 \mathrm{ab}$ & $12,3 \mathrm{ab}$ & $11,6 \mathrm{ab}$ & $(-)$ \\
\hline Keterangan : & $11,7 \mathrm{ab}$ & $12,1 \mathrm{a}$ & $11,2 \mathrm{~b}$ & \\
& Angka pada baris dan kolom yang diikuti dengan huruf yang samatidak berbeda nyata menurut uji DMRT @ 5\%. \\
& (-): Tidak terjadi interaksi antar factor & &
\end{tabular}


Waktu aplikasi tidak berpengaruh secara nyata terhadap berat kering 100 biji tetapi data pada Tabel 11. menunjukkan bahwa kedelai yang diberikan pupuk kandang babi pada -21 HST menghasilkan setiap 100 biji kering yang lebih berat dan berat kering 100 biji kedelai yang diberikan pupuk kandang babi pada -14 HST paling ringan. Dosis pupuk kandang babi berpengaruh secara nyata terhadap berat kering 100 biji dimana kedelai yang diberikan pupuk kandang babi dengan dosis 15 t/ha menghasilkan setiap 100 biji kering yang paling berat dan berbeda nyata dengan berat kering 100 biji kedelai yang diberikan pupuk kandang babi dengan dosis 10 t/ha yang paling ringan.

3.12 Berat Kering Biji Per Petak

Hasil sidik ragam (Anova) menunjukkan tidak terjadi pengaruh interaksi antara waktu aplikasi dan dosis pupuk kandang babi terhadap berat kering biji per petak.

Tabel 12. Berat Kering Biji Per Petak (t/ha)

\begin{tabular}{ccccc}
\hline \multirow{2}{*}{ Waktu Aplikasi } & \multicolumn{3}{c}{ Dosis Pupuk } & \multirow{2}{*}{ Rerata } \\
\cline { 2 - 4 } & $5 \mathrm{t} / \mathrm{ha}$ & $10 \mathrm{t} / \mathrm{ha}$ & $1,576 \mathrm{a}$ \\
-7 HST & $1,943 \mathrm{a}$ & $1,281 \mathrm{a}$ & $1,504 \mathrm{a}$ & $1,629 \mathrm{a}$ \\
$-14 \mathrm{HST}$ & $1,273 \mathrm{a}$ & $1,525 \mathrm{a}$ & $2,090 \mathrm{a}$ & $1,185 \mathrm{a}$ \\
\hline -21 HST & $1,018 \mathrm{a}$ & $1,191 \mathrm{a}$ & $1,347 \mathrm{a}$ & $(-)$ \\
\hline Rerata & $1,412 \mathrm{a}$ & $1,332 \mathrm{a}$ & $1,647 \mathrm{a}$ & \\
\hline Keterangan : & Angka pada baris dan kolom yang diikuti dengan huruf yang samatidak berbeda nyata menurut uji DMRT @ 5\%. \\
& ( - ) : Tidak terjadi interaksi antar factor & &
\end{tabular}

Pengaruh utama baik waktu aplikasi maupun dosis pupuk kandang babi tidak terjadi secara nyata terhadap berat kering biji per petak tetapi data Tabel 12. menunjukkan bahwa kedelai yang diberikan pupuk kandang babi pada -14 HST menghasilkan biji kering setiap petak yang lebih berat sedangkan kedelai yang diberikan pupuk kandang babi pada -21 HST menghasilkan biji kering setiap petaak yang paling ringan. Kedelai yang diberikan pupuk kandang babi dengan dosis 15 t/ha menghasilkan biji kering setiap petak yang yang lebih berat sedangkan kedelai yang diberikan pupuk kandang babi dengan dosis 10 t/ha menghasilkan biji kering setiap petak yang paling ringan.

3.13 Berat Segar Berangkasan

Hasil sidik ragam (Anova) menunjukkan tidak terjadi pengaruh interaksi antara waktu aplikasi dan dosis pupuk kandang babi terhadap berat segar berangkasan, tetapi hasil uji lanjut menunjukkan bahwa kedelai yang diberikan pupuk kandang babi pada -14 HST dengan dosis 15 t/ha memiliki berangkasan segar yang paling beratyang berbeda nyata dengan berat segar berangkasan kedelai yang diberikan pupuk kandang babi pada waktu yang sama dengan dosis 10 t/ha serta kedelai yang diberikan pupuk kandang babi pada -21 HST dengan dosis 5 t/ha dan 10 t/ha tetapi tidak berbeda nyata dengan kombinasi perlakuan yang lainnya.

Waktu aplikasi tidak berpengaruh secara nyata terhadap berat segar berangkasan tetapi data pada Tabel 13. menunjukkan bahwa kedelai yang diberikan pupuk kandang babi pada -7 HST memiliki berangkasan segar yang lebih berat dan berangkasan segar kedelai yang diberikan pupuk kandang babi pada -21 HST paling ringan. Dosis pupuk kandang babi berpengaruh secara nyata terhadap berat segar berangkasan dimana kedelai yang diberikan pupuk kandang babi dengan dosis 15 t/ha memiliki berangkasan segar yang palingberatdan berbeda nyata dengan berat segar berangkasan kedelai yang diberikan pupuk kandang babi dengan dosis 10 t/ha yang paling ringan.

Tabel 13. Berat Segar Berangkasan (t/ha)

\begin{tabular}{ccccc}
\hline \multirow{2}{*}{ Waktu Aplikasi } & \multicolumn{3}{c}{ Dosis Pupuk } & \multirow{2}{*}{ Rerata } \\
\cline { 2 - 4 } & $5 \mathrm{t} / \mathrm{ha}$ & $10 \mathrm{t} / \mathrm{ha}$ & $15 \mathrm{t} / \mathrm{ha}$ & $1,482 \mathrm{a}$ \\
-7 HST & $1,753 \mathrm{ab}$ & $1,179 \mathrm{ab}$ & $1,514 \mathrm{ab}$ & $1,396 \mathrm{a}$ \\
$-21 \mathrm{HST}$ & $1,212 \mathrm{ab}$ & $0,862 \mathrm{~b}$ & $2,114 \mathrm{a}$ & $1,119 \mathrm{a}$ \\
\hline Rerata & $1,009 \mathrm{~b}$ & $1,080 \mathrm{~b}$ & $1,268 \mathrm{ab}$ & $(-)$ \\
\hline Keterangan : & $1,325 \mathrm{ab}$ & $1,040 \mathrm{~b}$ & $1,632 \mathrm{a}$ & \\
& Angka pada baris dan kolom yang diikuti dengan huruf yang samatidak berbeda nyata menurut uji DMRT @ 5\%.
\end{tabular}

\subsection{Berat Kering Berangkasan}

Hasil sidik ragam (Anova) menunjukkan tidak terjadi pengaruh interaksi antara waktu aplikasi dan dosis pupuk kandang babi terhadap berat kering berangkasan, tetapi hasil uji lanjut menunjukkan bahwa kedelai yang diberikan pupuk kandang babi pada -14 HST dengan dosis 15 t/ha memiliki berangkasan kering yang paling berat yang berbeda nyata dengan berat kering berangkasan kedelai yang diberikan pupuk kandang babi pada waktu yang sama dengan dosis $10 \mathrm{t} / \mathrm{ha}$ tetapi tidak berbeda nyata dengan kombinasi perlakuan yang lainnya.
Waktu aplikasi tidak berpengaruh secara nyata terhadap berat kering berangkasan tetapi data pada Tabel 14. menunjukkan bahwa kedelai yang diberikan pupuk kandang babi pada -14 HST memiliki berangkasan kering yang lebih berat dan berangkasan kering kedelai yang diberikan pupuk kandang babi pada -21 HST paling ringan. Dosis pupuk kandang babi berpengaruh secara nyata terhadap berat kering berangkasan dimana kedelai yang diberikan pupuk kandang babi dengan dosis 15 t/ha memiliki berangkasan kering yang paling berat dan berbeda nyata dengan berat kering berangkasan kedelai yang diberikan pupuk kandang babi dengan dosis 10 t/ha yang paling ringan.

Tabel 14. Berat Kering Berangkasan (t/ha)

\begin{tabular}{|c|c|c|c|c|}
\hline \multirow{2}{*}{ Waktu Aplikasi } & \multicolumn{3}{|c|}{ Dosis Pupuk } & \multirow{2}{*}{ Rerata } \\
\hline & $5 \mathrm{t} / \mathrm{ha}$ & $10 \mathrm{t} / \mathrm{ha}$ & $15 \mathrm{t} / \mathrm{ha}$ & \\
\hline$-7 \mathrm{HST}$ & $0,771 \mathrm{ab}$ & $0,527 \mathrm{ab}$ & $0,762 \mathrm{ab}$ & $0,687 \mathrm{a}$ \\
\hline-14 HST & $0,650 \mathrm{ab}$ & $0,446 \mathrm{~b}$ & $1,118 \mathrm{a}$ & $0,738 \mathrm{a}$ \\
\hline$-21 \mathrm{HST}$ & $0,593 \mathrm{ab}$ & $0,511 \mathrm{ab}$ & $0,644 \mathrm{ab}$ & $0,583 \mathrm{a}$ \\
\hline Rerata & $0,671 \mathrm{ab}$ & $0,495 \mathrm{~b}$ & $0,842 \mathrm{a}$ & $(-)$ \\
\hline
\end{tabular}

\subsection{Indeks Panen}

Hasil sidik ragam (Anova) menunjukkan tidak terjadi pengaruh interaksi antara waktu aplikasi dan dosis pupuk kandang babi terhadap indeks panen.

Pengaruh utama baik waktu aplikasi maupun dosis pupuk kandang babi tidak terjadi secara nyata terhadap indeks panen tetapi data pada Tabel 15 menunjukkan bahwa kedelai yang diberikan pupuk kandang babi pada -7 HST memiliki nilai indeks panen yang lebih tinggi sedangkan kedelai yang diberikan pupuk kandang babi pada -21 HST memiliki nilai indeks panen yang paling rendah. Kedelai yang diberikan pupuk kandang babi dengan dosis 10 t/ha memiliki nilai indeks panen yang lebih tinggi sedangkan kedelai yang diberikan pupuk kandang babi dengan dosis 5 t/ha memiliki nilai indeks panen yang paling rendah.

Tabel 15. Indeks Panen (\%)

\begin{tabular}{ccccc}
\hline \multirow{2}{*}{ Waktu Aplikasi } & \multicolumn{3}{c}{ Dosis Pupuk } & \multirow{2}{*}{ Rerata } \\
\cline { 2 - 4 } & $5 \mathrm{t} / \mathrm{ha}$ & $10 \mathrm{t} / \mathrm{ha}$ & $70,1 \mathrm{a}$ \\
-7 HST & $72,4 \mathrm{a}$ & $69,9 \mathrm{a}$ & $68,0 \mathrm{a}$ & $68,0 \mathrm{a}$ \\
-14 HST & $63,6 \mathrm{a}$ & $74,9 \mathrm{a}$ & $65,6 \mathrm{a}$ & $67,0 \mathrm{a}$ \\
\hline Rerata & $64,0 \mathrm{a}$ & $69,6 \mathrm{a}$ & $67,4 \mathrm{a}$ & $(-)$ \\
\hline Keterangan $:$ & $66,7 \mathrm{a}$ & $71,5 \mathrm{a}$ & $67,0 \mathrm{a}$ & \\
\hline
\end{tabular}

( - ) : Tidak terjadi interaksi antar factor 


\subsection{Pembahasan}

Waktu aplikasi pupuk kandang babi secara umum tidak berpengaruh terhadap pertumbuhan dan hasil tanaman. Hasil berupa biji kering setiap petak yang paling tinggi dihasilkan dari tanaman yang diberikan pupuk kandang babi pada waktu -14 HST walaupun jumlah polong setiap tanaman, jumlah biji per polong dan berat kering biji setiap tanaman yang tidak terlalu tinggi. Pertumbuhan vegetatif tanaman yang diberikan pupuk kandang babi pada waktu -14 HST tidak terlalu mendominasi, hal ini terlihat dari tanaman yang tidak terlalu tinggi dengan batang yang juga tidak terlalu besar, luas permukaan daun yang sedang hingga berangkasan segar tanaman yang tidak terlalu berat.

Pemberian pupuk kandang babi dengan dosis 15 t/ha memberikan kondisi lingkungan berupa suhu tanah yang tidak terlalu tinggi pada masa awal dan pertengahan masa pertumbuhan serta suhu yang menjadi lebih rendah diakhir pertumbuhan. Kadar lengas tanah sedikit meningkat dari awal pengamatan hingga pengamatan kedua akibat terjadinya hujan selama beberapa hari, tetapi kembali menurun saat pengamatan terakhir. Tanah pada petak yang diberikan pupuk kandang babi dengan dosis 15 t/ha juga lebih gembur tetapi menjadi semakin padat dari awal hingga pengamatan yang terakhir. Pada pengamatan pertama, kedelai yang diberikan pupuk kandang babi dengan dosis $15 \mathrm{t} / \mathrm{ha}$ tidak terlalu tinggi dan berbatang yang tidak terlalu besar tetapi pada pengamatan selanjutnya hingga pengamatan terakhir tanaman menjadi paling tinggi dengan batang yang paling besar walaupun permukaan daunnya tidak terlalu luas sehingga berangkasan segar dan kering juga paling berat. Hasil tanaman juga lebih baik berupa polong pada setiap tanaman yang lebih banyak dengan ukuran polong yang lebih panjang sehingga walaupun jumlah biji dalam setiap polongnya tidak terlalu banyak dengan 100 biji yang lebih ringan tetapi biji kering yang dihasilkan setiap tanaman maupun setiap petaknya paling berat.

Walaupun pengaruh interaksi dari waktu aplikasi dan dosis pupuk kandang babi tidak terjadi pada semua parameter pertumbuhan dan hasil kedelai tetapi kedua perlakuan tersebut merupakan satu kesatuan tindakan dalam kegiatan pemupukan sehingga tetap perlu diperhatikan dalam pelaksanaan dilapangan dimana dapat dilihat bahwa jika pupuk kandang babi diberikan pada -14 HST dengan dosis 15 t/ha maka akan mencapai hasil yang lebih tinggi dari efek masing-masing perlakuan secara terpisah.

\section{Simpulan}

Dari analisis hasil dan pembahasan yang dilakukan maka disimpulkan beberapa hal sebagai berikut:

a. Tidak terjadi pengaruh interaksi antara waktu aplikasi dan dosis pupuk kandang babi terhadap terhadap semua parameter pertumbuhan dan hasil kedelai.

b. Waktu aplikasi hanya berpengaruh secara nyata terhadap diameter batang 28 HST, sedangkan dosis pupuk berpengaruh secara nyata terhadap tinggi tanaman 14 HST, diameter batang 42 HST, luas daun, berat kering 100 biji dan berat segar maupun berat kering berangkasan.

c. Pemberian pupuk kandang babi pada -14 HST adalah waktu yang tepat dan memberikan hasil kedelai 1,629 t/ha. Dosis 15 t/ha merupakan dosis yang lebih baik dan memberikan hasil kedelai 1,647 t/ha. Jika pemberian pupuk kandang babi dilakukan pada -14 HST dengan dosis 15 t/ha maka hasil kedelai mencapai 2,090 t/ha.

\section{Pustaka}

Ahmed S I, Steven K, Mickelson, Carl H. Pederson, James L. Baker. 2013. Swine Manure Rate, Timing, and Application Method Effects on PostHarvest Soil Nutrients, Crop Yield, and Potential Water Quality Implications in a Corn-Soybean Rotation. Agricultural and Biosystems Engineering Publications. 56(2):395-408.

Badan Pusat Statistik. 2014. Statistik Indonesia. BPS RI.Jakarta.

Badan Pusat Statistik TTU. 2007.Timor Tengah Utara Dalam Angka. BPS TTU. Kefamenanu.

Djajadiningrat S T.1991. Penilaian secara cepat sumber-sumber pencemaranair, tanah dan udara. Gadjah Mada University press

Gomez K A dan Gomez A A. 1995. Prosedur Statistik untuk Penelitian Pertanian. Edisi ke 2. Jakarta: UI Press.

Harsono H. 1991. Pencemaran. Gajamada University Press. Yogyakarta.

Santoso. 1994. Kecap dan Tauco Kedelai. Kanisius. Yogyakarta.

Suprapto. 1997.Bertanam kedelai. Penerbit Swadaya, Jakarta.

Suriawiria. 2007.Mikrobiologi Umum. Departemen biologi FMIPA. ITB. Bandung. 